\title{
BRS FS305 - COMMON BEAN CULTIVAR WITH CALIMA BEAN FOR EXPORT
}

D Helton Santos Pereira ${ }^{1 *}$, (D) Maria José Del Peloso ${ }^{1}$, (D) Thiago Lívio Pessoa Oliveira de Souza ${ }^{1}$, (D) Luís Cláudio de Faria ${ }^{1}$, (1) Marcelo Sfeir de Aguiar ${ }^{1}$, (D) Adriane Wendland ${ }^{1}$, (D) Joaquim Geraldo Cáprio da Costa ${ }^{1}$, (D) José Luis Cabrera Díaz ${ }^{1}$, (1) Mariana Cruzick de Souza Magaldi ${ }^{1}$, (1) Ângela de Fátima Barbosa Abreu ${ }^{1}$, (1) Israel Alexandre Pereira Filho², (D) Válter Martins de Almeida $^{3}$, (1) Maurício Martins ${ }^{4}$, (1) Leonardo Cunha Melo ${ }^{1}$.

1 Embrapa Arroz e Feijão, 75.375-000, Santo Antônio de Goiás, GO, Brazil;

2 Embrapa Milho e Sorgo, Rod. MG-424, km 45, Sete Lagoas, C.P. 285, 35.701-970,

Sete Lagoas, MG, Brazil;

3 Empresa Mato-grossense de Pesquisa, Assistência e Extensão Rural, 78.049-903,

Cuiabá, MT, Brazil,

4 Universidade Federal de Uberlândia (UFU), 38.400-902, Uberlândia, MG, Brazil.

* Corresponding author: Helton Santos Pereira (helton.pereira@embrapa.br)

\begin{abstract}
BRS FS305 is a common bean cultivar with calima bean and international standard size (67 g per 100 seeds), indicated for cultivation in Central Brazil and Paraná. It has a semiearly cycle, yield potential of $3,615 \mathrm{~kg} \mathrm{ha}^{-1}$ and is moderately resistant to rust, anthracnose and angular leaf spot.
\end{abstract}

Keywords: Phaseolus vulgaris, international market, special grains.

\section{Introduction}

Brazil is one of the world's largest producers of common bean (Phaseolus vulgaris L.), which is a traditional part of the Brazilian diet and consumed across all social classes. In 2017, the total common bean production in the country was 2.5 million tons (Feijão, 2019). The commercial grain classes of carioca and black beans, of Mesoamerican origin, account for $85 \%$ of the Brazilian output. However, there is a demand for other grain types, with higher added value and the possibility of export (Del Peloso and Melo, 2005), since the carioca bean, which accounts for $75 \%$ of the Brazilian production, is not consumed on a large scale internationally. The commercial grain classes of major international interest are cranberry, sugar bean, white, dark red kidney (DRK), light red kidney (LRK) and calima. The calima bean class, of Andean origin, has a 100seed weight between 50 and $70 \mathrm{~g}$ and is very popular in Africa. Historically, common bean breeding programs in Brazil have given little priority to Andean beans, mainly those with grain types preferred on international markets. Consequently, few cultivars are available, resulting in a low domestic production and high imports of these grain types from abroad. Currently, some breeding programs have focused on the identifycation and development of such lines to improve the adaptation to the soil and climate conditions 
of the country (Gonçalves et al., 2009; Pereira et al., 2014).

The indication of new cultivars has contributed to increase common bean yield in Brazil (Feijão, 2014). Therefore, new lines with better phenotypes must constantly be sought. The common bean breeding program of Embrapa Rice and Beans is in search for cultivars with high yield potential, better disease resistance and an upright plant architecture, to enable bean harvest mechanization, so that the farmers can offer consumers a better quality product and improve the return on their investment in the crop. In this sense, new cultivars with internationally consumed grains were indicated for planting in Brazil, in the last years, e.g., BRSMG Realce (Melo et al., 2014), with striped grains; BRS Embaixador (Aidar et al., 2008), with DRK beans; BRS Executivo (Aidar et al., 2008), with sugar bean grains; BRS Ártico (Pereira et al., 2016), with white beans; IAC Nuance, with cranberry beans; and IAC Tigre, with pinto beans. However, only one cultivar of the calima group is registered: IAC Boreal (Chiorato et al., 2008) developed by the Agronomic Institute of Campinas (IAC).

\section{Breeding methods}

Cultivar BRS FS305 resulted from the lines Calima-2 and Argentino 1, which were crossed in 1985, at the International Center of Tropical Agriculture, Cali, Colombia (CIAT). The genera- tions were also advanced in Colombia to develop the lines. Between 2007 and 2016, line CAL-96 was introduced in Brazil and evaluated in the field for plant architecture, lodging tolerance, grain yield and commercial quality, reaction to angular leaf spot, anthracnose, fusarium wilt, rust, common bacterial blight and bacterial wilt. In 2007, 2008, 2009, 2010, 2015 and 2016, the line was evaluated in Goiás, Minas Gerais and Mato Grosso in the winter, and in Paraná during the rainy and dry seasons, in a total of 40 evaluation environments. Five controls were used in these tests: BRS Embaixador, Hooter, BRS Executivo, BRS Ártico, and BRS Radiante. The experiment was arranged in a randomized block design with three replications and plots of four 4meter rows, using the technologies recommendded for the different common bean cultivation systems.

\section{Grain yield and yield potential}

In 40 tests for the Value for Cultivation and Use (VCU) carried out in 2007, 2008, 2009, 2010, 2015 and 2016, during the winter growth season in Goiás, Minas Gerais and Mato Grosso, and in the rainy and dry growth seasons in Paraná, cultivar BRS FS305 (CAL-96) exceeded the mean of the controls (BRS Embaixador, BRS Executivo, Hooter, BRS Ártico and BRS Radiante) by $7.5 \%$ (Table 1 ).

Table 1. Mean grain yield $\left(\mathrm{kg} \mathrm{ha}^{-1}\right)$ of cultivar BRS FS305 compared to the mean yield of the controls in the Value for Cultivation and Use (VCU) tests, in each state and sowing season.

\begin{tabular}{cccccccc}
\hline State & Season & BRS FS305 & Control 1 & Control 2 & $\begin{array}{c}\text { Control } \\
\text { mean }\end{array}$ & $\begin{array}{c}\text { Relative } \\
\text { yield (\%) }\end{array}$ & $\begin{array}{c}\text { Number of } \\
\text { environments }\end{array}$ \\
\hline PR & Rainy & 1,526 & 1,314 & 1,481 & 1,398 & 110.0 & 8 \\
\hline PR & Dry & 2,824 & 1,959 & 1,792 & 1,876 & 112.9 & 7 \\
\hline PR & Overall & 1,807 & 1,615 & 1,626 & 1,621 & 111.3 & 15 \\
\hline MG & Winter & 2,454 & 2,335 & 2,207 & 2,271 & 107.0 & 8 \\
\hline MT & Winter & 2,370 & 2,583 & 1,927 & 2,255 & 105.3 & 2 \\
\hline GO & Winter & 2,216 & 2,218 & 1,920 & 2,069 & 108.1 & 15 \\
\hline RII* & Winter & $\mathbf{2 , 3 0 5}$ & $\mathbf{2 , 2 8 5}$ & $\mathbf{2 , 0 1 2}$ & $\mathbf{2 1 4 9}$ & 107.5 & 25 \\
\hline Over-all & - & $\mathbf{2 , 1 1 8}$ & $\mathbf{2 , 0 3 3}$ & $\mathbf{1 , 8 6 8}$ & $\mathbf{1 , 9 5 1}$ & $\mathbf{1 0 9 . 0}$ & $\mathbf{4 0}$ \\
\hline
\end{tabular}

1) BRS Embaixador or BRS Radiante; 2) BRS Executivo, Hooter or BRS Ártico; * Region II - ES, RJ, GO, DF, MG, MT, TO, BA and MA;

These control cultivars were chosen because of their large grains, Andean origin and because they are promising for export, even when the commercial class was different from that of BRS FS305. This approach was used since at the beginning of the VCU tests, no other cultivars had the same grain pattern as BRS FS305. Cultivars BRS Executivo and Hooter have sugar and cranberry beans, respectively. BRS Embaixador has DRK and BRS Ártico white beans. BRS Radiante has the typically striped grains of the domestic market, which are occasionnally 
exported when the production in tradetionnal bean-exporting countries of other grain types is low. Sugar bean, cranberry and striped bean types have similar colors (cream grains with red stripes) that differ in grain size and shape.

The overall yield mean of BRS FS305 was $2,118 \mathrm{~kg} \mathrm{ha}^{-1}$, compared to $1,951 \mathrm{~kg} \mathrm{ha}^{-1}$ of the controls (Table 1). In the different states and regions of indication (Pereira et al., 2010), BRS FS305 produced a mean yield of $2,305 \mathrm{~kg} \mathrm{ha}^{-1}$ in Region II (Espírito Santo, Rio de Janeiro, Mato Grosso, Goiás, Federal, Bahia, Tocantins and Maranhão) and a mean yield of $1,807 \mathrm{~kg} \mathrm{ha}^{-1}$ in the state of Paraná. The yield potential of BRS FS305, averaged across the five tests with its highest yields, was $3,615 \mathrm{~kg} \mathrm{ha}^{-1}$. This estimate shows the high genetic potential of the cultivar and that high yields can be achieved if the environment and growing conditions are favorable. The yield of this cultivar is higher than that of others with export standard beans with, e.g., the cultivars BRS Executivo, BRS Embaixador and BRS Ártico.

\section{Other traits}

With regard to the technological and industrial quality traits of cultivar BRS FS305, the beans have a regular color and size, with a mean 100-seed weight of $67 \mathrm{~g}$, lower than that of cultivar BRS Executivo (76 g) and superior to BRS Embaixador (63g) and IAC Boreal $(50 \mathrm{~g})$, which also have calima beans (Table 2). The mean cooking time of BRS FS305 is 25 min., i.e., within the range observed for other grain types. Regarding the protein percentage, the mean content of BRS FS305 (22.7\%) is within the standard range for common bean.

Under artificial inoculation, BRS FS305 is resistant to the pathotypes $65,73,81,89,475$ and 1609 of Colletotrichum lindemuthianum, the causal agent of anthracnose. In the field trials, the cultivar was moderately resistant to anthracnose, rust and angular leaf spot. On the other hand, it was susceptible to bacterial wilt, fusarium wilt, common bacterial blight and golden mosaic (Table 3).

Table 2. Grain traits of common bean cultivar BRS FS305, compared to the controls BRS Executivo, BRS Embaixador, BRS Ártico and BRS Radiante.

\begin{tabular}{lcccc}
\hline Cultivar & Bean type & Cooking time (min.) & Protein percentage (\%) & 100-seed weight (g) \\
\hline BRS FS305 & Calima & 25 & 22.7 & 67 \\
\hline BRS Executivo & Sugar bean & 28 & 24.8 & 76 \\
\hline BRS Embaixador & Dark red kidney & 20 & 21.4 & 63 \\
BRS Ártico & White & 26 & 23.5 & 62 \\
\hline BRS Radiante & Striped & 32 & 22.3 & 44 \\
\hline
\end{tabular}

Table 3. Agronomic traits and disease reaction of cultivar BRS FS305, compared to controls BRS Ártico, BRS Embaixador and BRS Executivo.

\begin{tabular}{lcccccccccc}
\hline Cultivar & Cycle & ARCH & AN & CBC & RU & ALF & BCMV & BGMV & FOP & BW \\
\hline BRS FS305 & SE & Semi-upright & MR & S & MR & MS & NI & S & S & S \\
\hline BRS Ártico & SE & Upright & MS & S & MR & S & NI & S & MS & MR \\
\hline BRS Executivo & N & Semi-upright & MS & S & S & S & S & S & MR & MR \\
\hline BRS Embaixador & SE & Upright & MR & S & S & S & S & S & MR & S \\
\hline
\end{tabular}

ARCH- Plant architecture; AN- Anthracnose; CBC- Common bacterial infection; RU- Rust; ALF- Angular leaf spot; BCMV- Bean common mosaic virus; BGMV- bean golden mosaic virus; FOP- Fusarium wilt; BW- Bacterial wilt; NNormal Cycle; SE- Semi-early cycle; R- Resistant; MR- Moderately resistant; MS - Moderately susceptible; SSusceptible; NI- no information.

Similarly to BRS Embaixador, BRS FS305 has a semi-early cycle (75 - 84 days, from emergence to physiological maturity). The plants are shrubby, with a type II indeterminate growth habit. In terms of plant architecture, BRS FS305 is semi-upright and has intermediate lodging tolerance. However, due to the short plant height, direct mechanical harvesting (harvest and threshing in one operation) may not be efficient in all cases. The flowers are white and at physiological maturity, the pods are purplish yellow. At harvest maturity however, the pods are straw yellow. The beans of the calima type (purple with cream stripes) have a full long shape and no gloss. 
Particular traits of BRS FS305 are the export-standard calima beans, higher yields than other cultivars for grain export and a semi-early cycle. This new cultivar will allow Brazilian producers to offer a product that meets international standards on the foreign market, which has expanded extremely in recent years, with high price stability and good prospects for economic returns.

\section{Seed production}

Cultivar BRS FS305 was registered (no. 36757) by the Ministry of Agriculture, Livestock and Supply. Embrapa is in charge of the basic seed production.

\section{Conclusions}

The common bean cultivar BRS FS305, with calima bean, has a semi-early cycle, high yield potential and excellent grain quality, which meets the requirements of the international market. BRS FS305 is indicated for sowing in the following states and sowing seasons: in the winter, in the states of Goiás, Federal District, Mato Grosso, Tocantins, Maranhão, Bahia, Espírito Santo and Rio de Janeiro; and in the rainy and dry seasons, in the state of Paraná.

\section{Acknowledgements}

The authors wish to thank the International Center for Tropical Agriculture (CIAT), for providing the line for evaluation in Brazil and the documentation authorizing Embrapa to register the cultivar. They are indebted to the partner institutions that contributed to the evaluation of the cultivar: Embrapa Rice and Beans; Embrapa Technology Transfer; Emater Goiás; Universidade do Centro-Oeste; Fundação de Ensino Superior de Rio Verde; Embrapa Cerrados; Embrapa Maize and Sorghum; Federal University of Lavras; Federal University of Uberlândia; Agricultural Research Company of Minas Gerais; Agricultural research company and rural extension of Mato Grosso; Federal Goian Institute; Lutheran Institute of Higher Education/Lutheran University of Brazil; Embrapa Soybean.

\section{References}

AIDAR, H.; THUNG, M.D.; KLUTHICOUSKI, J.; SOARES, D.M.; DEL PELOSO, M.J.; FARIA, L.C.; MELO, L.C.; COSTA, J.G.C.; RAVA, C.A.; PEREITA, H.S.; DÍAZ, J.L.C.; SILVA, H.T.; SARTORATO, A.; FARIA, J.C.; BASSINELLO, P.Z. 2008. BRS Embaixador - Dark red kidney common bean for international market. Annual Report of the Bean Improvement Cooperative, 51:274-275.

AIDAR, H.; THUNG, M.D.; KLUTHICOUSKI, J.; SOARES, D.M.; DEL PELOSO, M.J.; FARIA, L.C.; MELO, L.C.; COSTA, J.G.C.; RAVA, C.A.; PEREIRA, H.S.; DÍAZ, J.L.C.; SILVA, H.T.; SARTORATO, A.; FARIA, J.C.; WENDLAND, A. 2008. BRS Executivo - Cranberry common bean for international market. Annual Report of the Bean Improvement Cooperative, 51:276-277.

DEL PELOSO, M.J.; MELO, L.C. 2005. Potencial de rendimento da cultura do feijoeiro comum. Embrapa Arroz e Feijão, Santo Antônio de Goiás, 131p.

CHIORATO, A.F.; CARBONELL, S.A.M.; ITO, M.F.; BENCHIMOL, L.L.; COLOMBO, C.A.; PERINA, E.F.; ITO M.A.; RAMOS JUNIOR, E.U.; FREITAS, R.S.; PEREIRA, J.C.V.N.A. 2008. IAC Boreal and IAC Harmonia: common bean cultivares with striped grains. Crop Breeding and Applied Biotechnology, 8:170-173.

FEIJÃO: Dados conjunturais do feijão (área, produção e rendimento) (Phaseolus vulgaris L.) no Brasil - 1985 a 2017. Acesso em: 28 de Janeiro, 2019. 
GONÇALVES, J.G.R.; CHIORATO, A.F.; MORAIS, L.K.; PERINA, E.F.; FARIAS, F.L.; CARBONELL, S.A.M. 2010. Estudo da estabilidade fenotípica de feijoeiro com grãos especiais. Ciência e Agrotecnologia, 34: 922-931. https://doi.org/10.1590/S1413$\underline{70542010000400018}$

MELO, L.C.; ABREU, A.F.B.; RAMALHO, M.A.P.; CARNEIRO, J.E.S.; PAULA JÚNIOR, T.J.; DEL PELOSO, M.J.; PEREIRA, H.S.; FARIA, L.C.; PEREIRA FILHO, I.A.; MOREIRA, J.A.A.; MARTINS, M.; VIEIRA, R.F.; MARTINS, F.A.D.; COELHO, M.A.O.; COSTA, J.G.C.; WENDLAND, A.; SANTOS, J.B.; DIAZ, J.L.C.; CARNEIRO, P.C.S.; DEL GIÚDICE, M.P.; FARIA, J.C. 2014. BRSMG Realce: Common bean cultivar with striped grains for the state of Minas Gerais. Crop Breeding and Applied Biotechnology, 14:61-64. https://doi.org/10.1590/S1984-70332014000100010

PEREIRA, H.S.; BUENO, L.G.; DEL PELOSO, M.J.; ABREU, A.F.B.; MOREIRA, J.A.A.; MARTINS, M.; WENDLAND, A.; FARIA, L.C.; SOUZA, T.L.P.O.; MELO, L.C. 2014. Agronomic performance and stability of andean common bean lines with white beans in Brazil. Bragantia, 73:130-137. https://doi.org/10.1590/brag.2014.020

PEREIRA, H.S.; MELO, L.C.; SILVA, S.C.; DEL PELOSO, M.J.; FARIA, L.C.; COSTA, J.G.C.; MAGALDI, M.C.S.; WENDLAND, A. 2009. Regionalização de áreas produtoras de feijão comum para recomendação de cultivares no Brasil. Embrapa Arroz e Feijão, Santo Antônio de Goiás, 6p. (Embrapa Arroz e Feijão, Comunicado técnico, 187).

PEREIRA, H.S.; WENDLAND, A.; SOUZA, T.L.P.O.; FARIA, L.C.; DEL PELOSO, M.J.; THUNG, M.; KLUTHICOUSKI, J.; COSTA, J.G.C.; DÍAZ, J.L.C.; MAGALDI, M.C.S.; ABREU, A.F.B.; MARTINS, M.; PEREIRA FILHO, I.A.; MOREIRA, J.A.A.; MELO, L.C. 2016. BRS Ártico - Common bean cultivar with export-standard white bean. Crop Breeding and Applied Biotechnology, 16:163-166. https://doi.org/10.1590/1984-70332016v16n2c25 